\title{
Radicalization in Adolescence: the Identification of Vulnerable Groups
}

\author{
Carl Philipp Schröder ${ }^{1}$ (D) . Jannik Bruns ${ }^{1} \cdot$ Lena Lehmann $^{1} \cdot$ Laura-Romina Goede $^{1}$. \\ Thomas Bliesener $^{1} \cdot$ Samuel Tomczyk ${ }^{2}$
}

Accepted: 1 February 2022 /Published online: 4 March 2022

(c) The Author(s) 2022

\begin{abstract}
Given that the normative search for identity and belonging, as well as political socialization, plays an important role during adolescence, this life stage is characterized by high vulnerability to radicalization processes. When investigating the influence of different factors on radicalization processes, latent profile analysis can identify and analyze groups of adolescents with different vulnerabilities. Based on a sample of 6,715 ninth-graders from Germany, we identified six latent classes with specific vulnerabilities to right-wing attitudes as one possible outcome of radicalization. The results show that the class with the highest approval of right-wing statements mainly consists of male adolescents with a high sense of relative disadvantage and social deprivation. Specific family ties constitute a unique feature among those who are indifferent in their attitudes.
\end{abstract}

Keywords Radicalization $\cdot$ Right-wing extremism $\cdot$ Youth $\cdot$ Latent profile analysis

\section{Introduction}

The topic of radicalization can be approached from different scientific perspectives. While the different perspectives and approaches each possess blind spots, they can successfully complement one another (Pisoiu, 2013). Research also differs in terms of the point at which radicalization is examined. Radicalization is understood as a process, meaning that radicalization research ranges from early beginnings (e.g., prejudicial attitudes) to terrorist acts. Existing research on radicalization reveals that a large proportion of studies are based on retrospective analyses of the biographies of extremist offenders (Lützinger, 2010; Kudlacek et al., 2018; Aslan et al., 2018; Sageman, 2004; Silber \& Bhatt, 2007). These studies can help identify relevant characteristics throughout the life course. The goal is to examine the influence of certain factors on extremist attitudes or actions. Since analyses of offenders often have no control group and therefore no variance, quantitative survey data is used to

Carl Philipp Schröder

CarlPhilipp.Schroeder@kfn.de

1 Criminological Research Institute of Lower Saxony, Lützerodestraße 9, 30161 Hannover, Germany

2 Department Health and Prevention, University of Greifswald, Robert-Blum-Straße 13, 17489 Greifswald, Germany 
examine risk and protective factors for radicalization (Emmelkamp et al., 2020; Wolfowicz et al., 2020).

Radicalization is mostly understood to be a developmental process that begins early in the life course and can lead to extremism (Beelmann, 2020; Neumann, 2013). Since the beginnings of radicalization are often observed at a young age, many scholars have focused their theoretical approaches (Horgan et al., 2017b; Meeus, 2015) and their empirical work (Bloom \& Horgan, 2019; Cherney, 2020; Cherney et al., 2020) on adolescents. Radicalization is generally understood as a process that is characterized by a complex interplay of individual, social, and societal factors and manifests itself in ideas, attitudes, and behaviors that are not in line with democratic and constitutional social contexts (Beelmann, 2020). To support deradicalization and prevent extremist acts, it is necessary to take an in-depth look at radicalization processes, as well as their causes and trajectories, to develop tailored and effective prevention methods.

Previous research suggests that radicalization processes can best be explained by a model of cumulative or mutually influencing conditional factors, whereby very different paths to radicalization can occur (Herding, 2013). Many theoretical models, as well as empirical studies, on radicalization have placed a focus on Islamism due to the fact that jihadist terrorism has been assessed as the greatest terrorist threat in the European Union (Europol, 2021). The highest number of twelve casualties resulting from a jihadist attack is closely followed by ten casualties related to a right-wing motivated terrorist attack (Europol, 2021). Nine victims were killed in one attack in Hanau, Germany. Ravndal et al. (2021) state that countries such as Germany and the UK have historically had a high incidence of attacks at a lower level, as evidenced by national hate crime statistics, for example. According to German police statistics, a total of 23,604 incidents of right-wing motivated hate crime were registered in 2020 (German Federal Ministry of the Interior, Building and Community, 2021a). These numbers increased by 5.7\% from 2019. German authorities state that right-wing motivated crime is the most relevant form of politically motivated crime in Germany (German Federal Ministry of the Interior, Building and Community, 2021b). Right-wing extremism is one of the most significant social problems and poses a major threat to minorities, as well as democracy itself. Therefore, we aim to analyze right-wing extremism as one potential outcome of radicalization.

Right-wing attitudes can influence political debates but can also influence the behavior of individuals or groups, who may subsequently become involved in extremist groups or commit violent acts. The ideologies behind hate crimes are highly problematic since they are generally related to an ideology of inequality, exclusion, and violence (Ahmed et al., 2020; Heine \& Magazzini, 2020; Heitmeyer, 2008). In the following, we refer to the most widely used definition among researchers in German-speaking countries, which is based on a consensus decision at the theoretical level and has received empirical support (Decker and Brähler, 2006). The definition states that "right-wing extremism is an attitude pattern that connectively represents an ideology of inequality. This is represented on the political level by an affinity toward authoritarian regimes, chauvinism, and the playing down or justification of National Socialism. On the social level, this ideology features antisemitic, xenophobic and social Darwinistic attitudes" (Kiess \& Decker, 2016, p. 15). Therefore, an analysis of attitude patterns is necessary to understand the conditions of origin and other risk factors associated with right-wing attitudes. Our analysis contributes to the understanding of patterns of right-wing attitudes and provides results that can potentially be used to inform prevention.

Various general German population surveys measure right-wing attitudes and find them to be widespread in society (Decker et al., 2020; Küpper et al., 2021). In a study from 2017, 
which was representative of ninth-graders in the federal state of Lower Saxony, Krieg and Kliem (2019) found a $2.5 \%$ affinity for right-wing regimes, $6.3 \%$ chauvinist attitudes, $10.9 \%$ xenophobic attitudes, and $3.0 \%$ antisemitic attitudes among adolescents without a migrant background. Another study by Krieg et al. (2018), which was representative of seventh- and ninth-graders in the federal state of Schleswig-Holstein, found a $6.7 \%$ affinity to right-wing regimes, $8.4 \%$ trivialization of National Socialism, $14.5 \%$ chauvinism, $15.3 \%$ xenophobia, $13.8 \%$ social Darwinism, and 5.8\% antisemitism among adolescents. Despite the differences in samples and measurement tools for the dimensions of right-wing attitudes in these studies, similar patterns emerge. Since most of the mentioned studies were repeated cross-sectional studies, these patterns were also found to be relatively stable over time.

However, these analyses only reflect differences on a variable level, usually represented by mean values or cut-off-based measures for each construct. While this approach provides information about the frequency of certain attitudes in the population, it does not allow for any conclusions about the interconnectedness of attitudes nor interpersonal variability. This is problematic because developmental research points to the interplay of different attitudinal factors as particularly relevant to radicalization trajectories (Beelmann, 2020). To capture the complexity of attitudinal patterns, accumulated statistical analyses do not suffice. The focus in research on broad, accumulated analyses on the variable level may neglect patterns specific to subgroups of the population which are informative for the development of tailored prevention measures. Therefore, person-centered methods are useful to complement frequently used variable-centered ones such as regression and factor analyses. Methods such as latent class analysis, as a type of finite mixture model, postulate a finite set of homogeneous and distinct mutually exclusive latent groups. These groups are responsible for the observed patterns in the data and can be identified by using probabilistic models (Collins \& Lanza, 2010). A latent class analysis can, for instance, examine different constellations of xenophobia, antisemitism, and social Darwinism within a population. This approach is highly flexible and compares models with multiple latent classes to identify the solution that best fits the data. Such an approach is thus of great importance for applied research (e.g., regarding the prevention of radicalization and violence) since variation across groups allows the identification of specific vulnerabilities and needs.

The present study focuses on right-wing attitudes among an adolescent sample. Since the working definition of right-wing attitudes comprises several distinct constructs, it is possible that there are latent groups that hold distinct attitudinal patterns, which are perhaps also connected to specific risk factors. By using a latent group analysis, it is possible to pave the way for potential innovation for tailored prevention measures and to explore the multi-faceted right-wing phenomenon from a different perspective. This approach has been successfully applied to related areas in youth development, such as racial identity (Seaton et al., 2012; Yu et al., 2019), perpetration of violence (Siller et al., 2020), and peer victimization (Wang et al., 2010). To our knowledge, however, there are no published studies that have thus far applied this analysis to right-wing attitudes among adolescents, which may also constitute a precursor of youth violence.

In the following, we will first describe the aspect of vulnerability by describing the importance of adolescence as a target age group and presenting key findings regarding relevant risk factors for right-wing attitudes. We assume that the patterns of these risk factors can reveal unique vulnerabilities of groups within the sample. We then describe the data collection procedure, the sample, and the instruments used for the analysis. An extensive description of the methodological approach of the latent class analysis is provided, highlighting its advantages over other methods. The "Results" section contains descriptive 
results as well as the results of latent class analysis and the multinomial logistic regression analyses, which include the latent classes as dependent variables. Finally, the discussion will highlight strengths and limitations of the study and conclude with implications for research, policy, and prevention practice.

\section{Vulnerability}

To determine which types of individuals are particularly susceptible to becoming involved with political extremism, it is necessary to identify risk factors. Likewise, certain factors can have a protective effect (i.e., they can prevent effects of radicalization processes; see Lösel et al., 2018). In this case, the risk factors may nevertheless apply, but the individuals are resilient. The vulnerability of certain groups or individuals can be described as the emergence of certain patterns or the sum of different risk factors. Risk factors are characteristics or circumstances of individuals that can influence and promote individual radicalization processes. Some authors differentiate between causal and correlational risk factors (Wolfowicz et al., 2020). Although our statistical analyses cannot clarify the causal impact, we will focus on risk factors that potentially have a predictive nature. Relevant factors can be derived from numerous theoretical radicalization models (Beelmann, 2020; McCauley \& Moskalenko, 2008; Moghaddam, 2005; Sageman, 2004; Veldhuis \& Staun, 2009). Research on radicalization and extremism provides a wide range of risk factor analyses. Some of these risk factors, however, only apply to Islamist extremism. Nevertheless, the majority of studies find similar factors for different spectrums of extremism. In this paper, we test multiple risk factors, of which some have previously only been analyzed in the context of Islamist radicalization studies. We focus on major risk factors that were identified in relevant research. It should be noted that other relevant risk factors, e.g., psychological problems (e.g., Bhui et al., 2014; Coid et al., 2016; Corner et al., 2016; Koehler, 2020; Sageman, 2004, 2008; Weatherston \& Moran, 2003) or peers (e.g., Baier et al., 2016; Dzhekova et al., 2017), may nevertheless have an impact on right-wing attitudes or radicalization, but are not included in the analyses because they go beyond the scope of the present study.

\section{Developmental Perspectives on Adolescence and Radicalization}

The specific focus on adolescence stems from the fact that this age group represents a particular stage of development. As previously mentioned, this age group has some specific characteristics that must be considered. During adolescence, individuals begin to search for their own identity. Furthermore, the parent-child relationship changes, partly because adolescents begin to seek independence. To analyze vulnerabilities among adolescents, some studies focus on risk factors that are relevant to the majority of adolescents, which are related to the occurrence of similar developmental experiences. Such factors include the search for belonging, provocative behavior, and general deviance. These factors can be caused by adolescents' biological and psychological development and are common within this age group. One established approach in criminology relates to the age-crime-curve (Farrington, 1986). This approach indicates a link between age and crime during adolescence. Many studies interpret this as an asymmetrical bell shape: from late childhood, the prevalence of offending increases, then peaks during adolescence, and decreases in adulthood. Although results may vary for specific groups (Klausen et al., 2016), this approach 
can be applied to radicalization research given that radicalization and, in particular, extremist attitudes and offences can be seen as a form of general deviance, which has been shown by adopted criminological approaches (e.g., Agnew, 2017; Wikström \& Bouhana, 2017; Rottweiler et al., 2021; Hsu \& Newman, 2017; Akins \& Winfree, 2017).

From a developmental perspective, adolescence represents a particularly relevant period for the development of identity, as well as norms and value systems. Adolescents are identified as an especially vulnerable group given that individuals begin to search for belonging, recognition, and identity around the ages of 14 to 16 (Greve, 2007). Furthermore, they seek adventures, thrills, and provocation (Benslama, 2017). Many risk factors related to radicalization play a particularly important role in adolescence (Benslama, 2017; Emmelkamp et al., 2020). Adolescence also constitutes an important phase for political socialization (Beelmann, 2020; Niemi \& Hepburn, 2010; Torney-Purta, 2004; Watts, 1999) and the development of attitudes that generally remain stable over the life course (Sears, 1983, 1990). Young people initially experiment with different political positions, which encourage both the adoption of extreme political positions and short-term changes in fundamental positions (Alwin \& Krosnick, 1991; Rekker et al., 2015). Extreme political positions and values are also regarded as an early characteristic of individual radicalization. Although it is possible that personal attitudes are generally not particularly stable during adolescence (Rekker et al., 2015), extremist attitudes are, nevertheless, prevalent among adolescents as many surveys from different countries have indicated (Krieg et al., 2020; Krieg et al., 2018; Baier et al., 2019; Muxel, 2020; Pfundmair et al., 2020; Cherney et al., 2020; Pauwels \& Waele, 2014). During puberty, adolescents increasingly detach themselves from their parents, and the importance of the peer group grows. Furthermore, adolescence does not just represent an age span, but rather a phase of life that is determined by school attendance, peer groups, family life, and social influence. Cognitive, motivational, social, and practical competencies (e.g., school and education, gender identity, peer relationships, lifestyle, norms and value systems, ethical and political awareness) must be acquired during adolescence. If identity crises are managed positively, for instance, via the support of family and friends, adolescents acquire a stable identity. Identity conflicts that are prolonged or particularly difficult to resolve can be seen as a risk factor for nonconforming behavior, which can include delinquency, but also extremism (Borum, 2012).

\section{Risk Factors for Developmental Trajectories into Right-Wing Attitudes}

To prevent developmental trajectories leading to right-wing attitudes and subsequent (violent) actions, a look at previous research on selected risk factors is necessary.

Gender Many criminological studies and police statistics show that males have a higher risk of engaging in criminal behavior (Arnis, 2016; Wong et al., 2010). Radicalization research also indicates gender differences within different ideologies, particularly in relation to recruitment processes and general gender roles (Orav et al., 2018). Empirical studies on right-wing attitudes, in particular, show higher values on all dimensions of right-wing attitudes (affinity to right-wing regimes, trivialization of National Socialism, chauvinism, xenophobia, social Darwinism, and antisemitism) among male adults (Decker et al., 2020; Küpper \& Zick, 2011; Küpper et al., 2021) and also among male ninth-graders (Bergmann et al., 2019). However, most studies do not consider gender within multivariate models, which indicates that other factors may hold greater explanatory power in relation to rightwing attitudes (Krieg et al., 2018). 
Critical life events and family bonds Drastic events can have a major impact on the lives of adolescents. The extent of the strain of these events depends not only on the nature of the events, but also on factors such as coping strategies and the resilience of adolescents (Agnew, 2010; Mansel \& Spaiser, 2013). According to criminological approaches, the social environment and, in particular, the family are important factors for coping and consequently avoiding deviance (Hirschi, 1969).

Deprivation Deprivation refers to a state of withdrawal, austerity, and a loss of or isolation from something familiar, as well as feelings of disadvantage. It is a subjective assessment of one's situation, treatment, or opportunities in comparison to others. Theories of deprivation assume that the subjectively perceived gap between the fulfillment or non-fulfillment of certain (especially economic) wishes and expectations is associated with the development of certain political orientations (Seipel \& Rippl, 2000). Runciman (1966) describes relative deprivation as a state in which an actor wants something that another one has. In this situation, the actor, when compared to the other one, is relatively deprived. It is not only a matter of an objectively worse situation for the actor, but also encompasses feelings of disadvantage, moral indignation, and anger (Böckler \& Zick, 2015; Kessler et al., 1999). This can encourage the search for like-minded individuals or groups, who also experience deprivation. Moreover, this can reinforce the underlying outrage, which can be consistent with right-wing ideologies and groups. According to some scholars, relative deprivation promotes the spread of right-wing attitudes, since, e.g., outgroups can be blamed for the feelings of disadvantage (Stöss, 2010; Heyer \& Gaßner, 2012; Schmitt et al., 2003). As an explanatory approach to right-wing extremist radicalization, deprivation can be particularly relevant to young people given that a lack of social capital (e.g., family support and education) worsens the chances of achieving social participation (Koehler, 2014). The development of young people's life goals is strongly influenced by societal expectations regarding desirable goals. Failure to achieve these goals thus harbors a high potential for frustration.

On the political level, general frustration about politics and the feeling of powerlessness are both labelled as political deprivation. On the social level, a lack of social support and feeling insecure within the social environment both refer to social deprivation.

Victimization and Discrimination Within criminology, victimization and discrimination are regarded as strains that can increase the risk of radicalization by impacting social control and self-control (Agnew, 2017; Wikström \& Bouhana, 2017; Wolfowicz et al., 2020). Radicalization models, mostly focusing on Islamist radicalization, particularly point to the effects of experiences of discrimination (Moghaddam, 2005; Sageman, 2008; Wiktorowicz, 2005). Few empirical studies identify experiences of discrimination as a weak predictor (Aslan et al., 2018). In many radicalization models and empirical studies, victimization and discrimination only play a role in the radicalization process if related to narratives that include a perceived collective feeling of injustice (Moghaddam, 2005; Neumann, 2016; Pauwels \& Heylen, 2020; Sageman, 2004). Experiences of victimization and discrimination are risk factors that can encourage young people to join extremist groups. In these groups, they may, for example, blame feelings of discrimination based on political orientation or experiences of physical violence on outgroups, thus linking individual experiences to a collective narrative. 
Delinquency Hate crime, as the conjunction of extremist attitudes and crime, can lead to the identification of a clear relationship between ideologies and criminality. Prominent figures of the extreme right, as well as the Islamist spectrum, often have a criminal record, yet the relationship between ideologies and criminal behavior is not clear given that extremist attitudes are far more prevalent than extremist acts (Campelo et al., 2018; Cherney, 2020; Oosterhoff et al., 2017). The relationship between extremist attitudes and behavior is, however, supported by studies (Kliem et al., 2018; Talaska et al., 2008).

\section{Method}

The present study is called "Perspectives of adolescents" and was conducted by the Criminological Research Institute of Lower Saxony in the frame of the project "Radicalisation within the digital age (RadigZ)," funded by the German Federal Ministry of Education and Research (BMBF). The study was designed to examine the risk potential of extremism among adolescents and to identify potential risk and protective factors for early radicalization (Goede et al., 2020).

\section{Procedure and Participants}

The ethics committee of the University of Göttingen approved all study measures. The study is based on a 90-min quantitative online questionnaire. The participants were ninth-graders from selected cities in 11 of the 16 federal German states in which the state school authorities approved the survey. The present study thus used a non-probability sample of the population of ninth-graders in Germany and did not aim to conduct representative data in the federal states, but aimed to conduct the survey in all schools of selected large and small cities, except for Special Educational Needs and vocational schools. Primarily those cities that had been highlighted in reports by the Federal Office for the Protection of the Constitution, which is the domestic intelligence agency responsible for the detection of extremist attempts (German Federal Ministry of the Interior, Building and Community, 2021b), as well as police and media reports with regard to their Islamism, right-wing, and left-wing extremism problems, were selected (Goede et al., 2020). Given that one of the original goals of the project was to analyze Islamist radicalization, we assumed a higher prevalence rate of extremist ideological beliefs in these cities and thus chose them in order to reach a sufficiently large number of relevant participants. The survey took place between January and December 2018, mostly during school hours. The data include various measurements of potential risk and protective factors, as well as right-wing, left-wing, and, most notably, Islamist attitudes and behaviors since data on this phenomenon are rare (Goede, 2019). Of all selected schools, 19\% agreed to participate in the survey, with a $65 \%$ student participation rate in these selected classes. In addition to the consent given by the state authorities and schools, the informed consent of parents and students was a prerequisite for participation. A trained test supervisor administered the study procedure in the classes. The questionnaire was only available in German and included questions on a variety of topics (e.g., political attitudes, religion, social environment, leisure activities, online activities, and deviant behavior, as well as discrimination and victimization experiences). Preliminary pilot testing of the questionnaire was conducted in six classes of different school types. We tested whether the time schedule was appropriate and whether the students understood the terminology used in the questionnaire. To ensure the comprehensibility of the items, we compared the questionnaire to previous studies conducted among ninth-graders 
(e.g., Bergmann et al., 2017) and additionally interviewed both teachers and students of the pre-tested classes.

The original sample contained 6,715 cases. For further analysis, the number of cases was reduced to 6,335. All deleted cases showed missing values on all items used in the latent profile analysis. The reasons for these missing values can differ. One reason may be related to the voluntary nature of the survey, which meant that participants were free to skip items if they did not want to answer or did not understand the item. Missing values can also indicate a premature end to the survey due to a lack of time, decreasing motivation, or the inability to participate for the duration of the survey. This leads to the possibility of an increased error variance due to careless responses. The completion rate of each survey page was checked, and no conspicuous rates were found for any of the pages, which indicate no systematic premature completion due to single items.

The majority of the 6,335 participants were 14 or 15 years old $(M=14.6 ; S D=0.70)$. However, the participants' age ranges from 13 to 19, which may be due to the inclusion of students who had skipped or repeated grade levels, as well as migrants or refugees that were assigned to the ninth grade. Gender was relatively equally distributed within the sample, with $52.9 \%$ of participants identifying as female. Most (58.7\%) of the participants attended a Gymnasium (i.e., A-Level equivalent). The percentage of ninth-graders that attended an Oberschule (i.e., secondary school) or a Gesamtschule (i.e., comprehensive school) is $27.2 \%$. Of the participants, $11.7 \%$ attended a Realschule (i.e., intermediate school) or an integrated Haupt- and Realschule (i.e., a combination of secondary and intermediate school). Only $2.3 \%$ of the sample attended a Hauptschule (i.e., lower secondary school). Of all students in the sample, $41.9 \%$ had a migrant background. Students who were themselves not born in Germany or did not have the German citizenship, or who had at least one parent who was not born in Germany or did not have German citizenship, are classified as having a migrant background. Of all participants in the sample, $93.7 \%$ were born in Germany and $94.8 \%$ were German citizens. Regarding religion, 28.8\% of participants identified as Protestant, 19.2\% as Catholic, and 3.5\% had another Christian denomination. The percentage of Muslims in the sample was $13.2 \%$, and the percentage of Jews was $0.6 \%$. Other religions were mentioned by $2.9 \%$ of the participants and $31.8 \%$ had no religion.

As in other studies (e.g., Decker et al., 2020; Küpper et al., 2021), the sample was not filtered by religious affiliation, migrant background, or other characteristics since all subgroups were expected to potentially show right-wing attitudes. The degree of identification with the German nation may differ between migrants and non-migrants or between participants with and without a migrant background. However, there was no precondition for answering the items measuring right-wing extremism in the questionnaire. Regarding the different dimensions of right-wing attitudes, xenophobia might be less relevant for people with migrant background. Nevertheless, dimensions such as the affinity to right-wing authoritarian regimes, trivialization of National Socialism, antisemitism, and social Darwinism can similarly occur among all subgroups and the data shows that the overall level of right-wing attitudes is nearly equal among participants with and without a migrant background (for a specific analysis of the data, see Goede et al., 2020).

\section{Instruments}

Right-wing Attitudes All items related to right-wing attitudes were measured using a fivepoint Likert scale, which ranged from (1) "completely disagree," (2) "tend to disagree," (3) "both agree and disagree," (4) "tend to agree" to (5) "completely agree." Right-wing 
attitudes are expressed via the agreement to items within a total of six relevant dimensions. Affinity to right-wing authoritarian regimes (e.g., "We should have a leader who rules Germany, with a strong hand, to the good of all"), chauvinism (e.g., "We should finally have the courage to, once again, hold a strong national feeling"), trivialization of National Socialism (e.g., "National Socialism also had positive aspects"), xenophobia (e.g., "There are too many foreigners living in Germany"), antisemitism (e.g., "Jews have too much influence in the world"), and social Darwinism (e.g., "There are valuable and unworthy lives"). The items were taken from the right-wing extremism scale by Decker et al. (2016) and have been tested and used in many studies (e.g., Decker et al., 2013; Decker et al., 2016; Decker et al., 2018, 2020; Küpper et al., 2021; Zick et al., 2019; Zick et al., 2016). In total, 13 items were used to measure right-wing attitudes. For the analysis, we calculated mean scales for all six dimensions, which each contained at least one item with a valid value.

Critical Life Events The participants were asked whether one or more of the following events had occurred as a stroke of bad luck: separation/divorce of parents, loss of friend(s) due to moving house, accident/sickness of a close relative, death of father, mother, or close relative. The accumulated variable ranged from 0 to 6.

Family Bonds To cover the different facets of family influences, three dimensions were considered. The first dimension is family cohesion, which uses items adapted from the Cohesion subscale of the Brief Family Relationship Scale (Fok et al., 2014). Four items were used to measure cohesion aspects such as familial commitment and a supportive family atmosphere (e.g., "In our family, we help and support one another"). The second dimension reflects parental control. The scale was adapted from Bergmann et al. (2019) and consists of four items (e.g., "There are fixed rules in our family"). The third dimension refers to family conflict and is adapted from Bergmann et al. (2019), which uses a scale that was first employed by Fok et al. (2014). The scale consists of five items (e.g., "In our family, there is much dispute").

Deprivation Political deprivation was measured using three items (e.g., "People like me have no influence on what the government does anyway"). Most items are taken from the GMF-Survey (group-focused enmity survey; Heitmeyer, 2002). Social deprivation was measured using two items that focus on satisfaction with the social environment (e.g., "There are enough people around me who take me as I am"). The items were taken from Heitmeyer (2002) and adapted for adolescents. ${ }^{1}$ The mean scale for social deprivation was inverted, so that high numbers indicate high social deprivation. Relative deprivation was measured using a singular item: the item "In comparison to how others live in Germany: How much do you think you personally receive?" could be answered with "less than the fair share," "a fair share," or "more than the fair share." The item is based on the ALLBUS survey (Gesis, 2017). For the analysis, this variable was transformed into dummy variables with 0 and 1 for "less than the fair share" and "more than the fair share" each. The reference category was "a fair share."

\footnotetext{
1 The items were rephrased so that the adolescent participants would find them easier to understand. In this case, the German phrase "in meiner unmittelbaren Umgebung" was changed to "In meinem Umfeld" for both items. Both phrases can be translated to "around me" or "in my environment". All items were tested for comprehensibility in extensive pretests (Goede et al., 2020).
} 
Victimization The victimization items were taken from the Lower Saxony Survey and have often been used among ninth-graders (Bergmann et al., 2017). Victimization consists of robbery, blackmail, physical injury with a weapon, individual personal injury, and multiple personal injury. The items were coded as either 0 or $1(1=$ if the offence applied $)$ and summated into the final variable, which ranged from 0 to 5 .

Discrimination The adolescents' discrimination experiences were measured using items from the Shell Youth Study (Albert et al., 2015). The participants were asked to indicate whether they had been "discriminated against or bullied" in the last 12 months for various reasons. The reasons, which could initially only be answered with "yes" or "no," referred to the adolescents' migrant background (here, there was the extra option of "I don't have a migrant background"), gender, appearance, political conviction, faith/religion, financial situation, sexual orientation, skin color, or no reason at all. The single items were coded as 0 or $1(1=$ if the reason applied) and summated into the final variable, which ranged from 0 to 9 .

Delinquency The measurement of delinquency was split into property offences and violent offences. The items were taken from Bergmann et al. (2017). Regarding the property offences, the adolescents were asked whether they had ever committed the following offences: theft, shoplifting, burglary, vehicle theft, damage to property, fare dodging, graffiti spraying, illegal downloading, or selling drugs. In addition to the property offences, the adolescents were asked to report whether they had ever committed the following six violent offences: assault and battery, multiple personal injury, physical injury by weapon, robbery, blackmail, and sexual violence. For both the property and violent offences, the single items were coded as 0 or $1(1=$ if the offence applied $)$ and summated into one variable. The final variable for property offences ranges from 0 to 9 and the variable for violent offences from 0 to 6 .

\section{Latent Profile Analysis and Logistic Regression}

The latent profile analysis (i.e., latent class analysis with continuous indicators) was based on scale values of chauvinism, xenophobia, social Darwinism, antisemitism, trivialization of National Socialism, and affinity to right-wing authoritarian regimes via Mplus 8 (Muthén \& Muthén, 2017). For the model estimation, robust maximum likelihood estimation (command MLR in Mplus), with 1000 sets of random start values, was chosen. The estimation process started with two latent classes or profiles (no right-wing attitudes vs. any). The number of latent profiles was subsequently increased to six, whilst comparing model fit between models.

There are several indicators that aid the selection process of the best fitting latent profile model. These indicators refer to overall model fit, parameter sparseness, classification quality, and theoretical tenability (Collins \& Lanza, 2010; Nylund et al., 2007; Tomczyk et al., 2016, 2018). The bootstrapped likelihood ratio test (BLRT) is a reliable indicator of overall model fit that compares the estimated model to a model with one less latent profile or class: a significant test indicates better fit of the currently estimated model. For each analysis, 50 random starts with 20 bootstrap draws were chosen. To evaluate parameter sparseness, we report the Akaike information criterion (AIC) and the sample-size adjusted Bayes information criterion (SSABIC). For both parameters, a lower value indicates greater sparseness. Classification quality is examined by looking at average latent class probabilities (ALCP) 
and entropy for each model. The values of both parameters range from 0 to 1 ; the closer to 1 , the better the classification of the model, meaning a clear distinction of latent classes or profiles. Here, a value of at least 0.7 is recommended (Nylund et al., 2007). Moreover, latent profiles need to be interpreted based on the literature and theoretical background (i.e., theoretical tenability). Therefore, the best latent profile model is selected on statistical criteria as well as content validity. Finally, we performed multinomial logistic regression models to compare predictors of latent profiles using the r3step command (Asparouhov \& Muthén, 2014). This approach considers uncertainty in latent group assignment when estimating latent profile models and respective regression coefficients and is thus more precise than, for instance, post hoc comparisons of latent classes based on most likely latent class membership. As predictors, we included relative deprivation, as well as social deprivation and political deprivation, number of critical life events, victimization, property offences and violent offences, and parental control, in addition to family conflict, and family cohesion. We report adjusted odds ratios (aOR), including 95\% confidence intervals, as effect sizes. We chose the latent profile with the lowest values on indicator variables as the reference group for statistical comparisons. All analyses were based on $\alpha=0.05$.

\section{Results}

\section{Descriptives}

Our analyzed sample contained 6,335 valid cases that could be assigned to one of the six latent classes. Overall, we found that the mean values for right-wing attitudes ranged from 1.66, for affinity to right-wing regimes, to 2.35, for chauvinism (see Table 1). Approval rates for most types of right-wing attitudes were low. However, a relatively high share of respondents showed agreement toward chauvinist and xenophobic attitudes. Concerning critical life events, $83.96 \%$ of the respondents had experienced at least one drastic event. Regarding relative deprivation, the majority of respondents felt that they received "a fair share" $(61.89 \%)$ or even "more than the fair share" $(31.83 \%)$, while only $6.28 \%$ of the respondents felt that they received "less than the fair share." The vast majority of adolescents considered their social environment to be supportive and were satisfied with it. Only $6.32 \%$ of the participants indicated that they felt socially deprived. A relatively larger share $(26.22 \%)$ of the participants could be described as politically deprived. Of all participants, $33.67 \%$ had experienced some form of discrimination or bullying at least once during the last 12 months. While the majority of respondents (73.85\%) had committed at least one property offence, relatively few respondents had been delinquent in regard to violent offences (14.25\%). Experiences of family cohesion and parental control were reported by the majority of adolescents in the sample $(84.03 \%, 83.59 \%)$. However, $16.97 \%$ of the respondents had experienced family conflict. In addition, $27.86 \%$ of the respondents had experienced victimization.

\section{Latent Profile Models}

To identify the best-fitting model, we examined the statistical criteria and interpretability of the latent profiles. The model fit criteria for models with two to six latent profiles are shown in Table 2. Except for entropy (favoring a model with three profiles), all criteria 
Table 1 Descriptives of relevant items

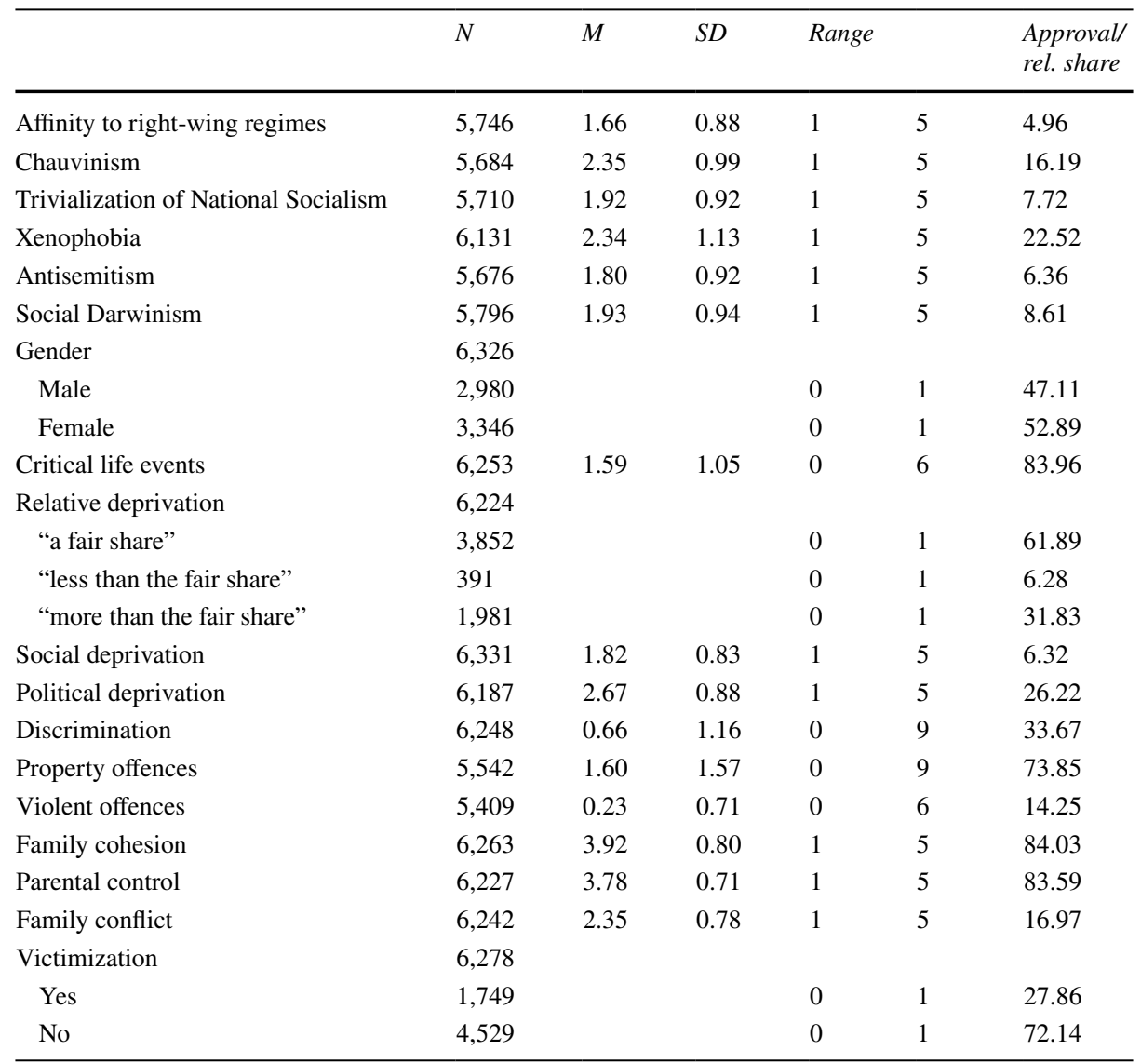

Approval for items with range from 1 to 5 by the addition of the share $>3$, relative share of all other items is percentage of the share $\geq 1$

favor a solution with six latent profiles. Since entropy and ALCP are above 0.8 for this model, and all profiles can be theoretically differentiated, this model was chosen.

The first class was the largest $(N=3,276)$ and had the lowest overall mean values for all items. In the following, this class is used as a reference for the other classes with problematic attitudes. This allows for the inclusion of the entire variance of students' attitudes in the analysis and can highlight a contrast between the classes. Given the clear disagreement with the statements on all dimensions of right-wing attitudes, these participants are referred to as "the opposing" class (see Fig. 1). The second class $(N=937)$ had low to moderate mean values for all items (approximately 0.7-1.0 scale points higher than the first class). These participants are labeled as "the generally opposing" class due to the disapproval of all items in the same pattern as "the opposing," but on a slightly lower level. The third class $(N=830)$ had low values regarding the affinity to right-wing authoritarian regimes but medium mean values for all other items. Therefore, these participants are labeled "the anti-authoritarians." The fourth class $(N=985)$ had medium mean values for all model items. Since participants in this class did not clearly agree or disagree with the 
Table 2 Model fit criteria for a latent profile analysis of political right-wing attitudes (chauvinism, xenophobia, social Darwinism, antisemitism, trivialization of National Socialism, affinity to right-wing authoritarian regime) in a sample of German ninth-graders

\begin{tabular}{llllll}
\hline Number of latent profiles & 2 & 3 & 4 & 5 & 6 \\
\hline Free parameters & 19 & 26 & 33 & 40 & 47 \\
Log-Likelihood & $-43,108.71$ & $-42,086.70$ & $-41,280.71$ & $-40,625.97$ & -40.153 .01 \\
BLRT & $9753.68 * * *$ & $2044.02 * * *$ & $1611.98 * * *$ & $1309.47 * * *$ & $\mathbf{9 4 5 . 9 2 * * *}$ \\
AIC & $86,255.42$ & $84,225.40$ & $82,627.42$ & $81,331.95$ & $\mathbf{8 0 , 4 0 0 . 0 3}$ \\
SSABIC & $86,323.37$ & $84,318.38$ & $82,745.43$ & $81,474.99$ & $\mathbf{8 0 , 5 6 8 . 1 0}$ \\
Entropy & 0.84 & $\mathbf{0 . 8 7}$ & 0.81 & 0.84 & 0.86 \\
ALCP & 0.97 & 0.96 & 0.91 & 0.92 & 0.81 \\
& 0.93 & 0.91 & 0.94 & 0.85 & 0.86 \\
& & 0.92 & 0.81 & 0.90 & 0.86 \\
& & & 0.89 & 0.92 & 0.92 \\
& & & & 0.78 & 0.87 \\
\end{tabular}

$B L R T$ bootstrapped likelihood ratio test; AIC Akaike information criterion; SSABIC sample-size-adjusted Bayes information criterion; $A L C P$ average latent class probabilities; $* * * p<0.001$; fit criteria indicating the best model are printed in bold

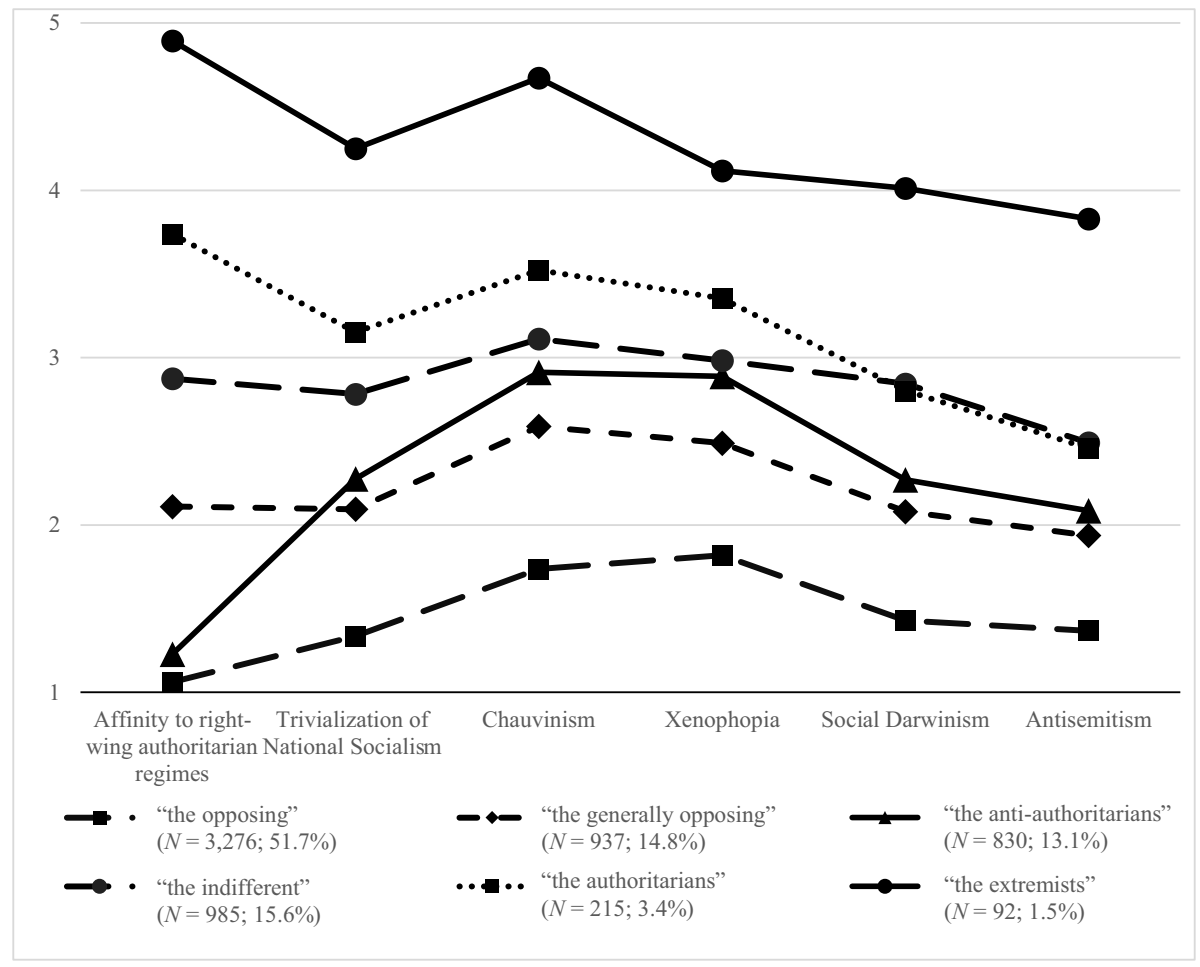

Fig. 1 Estimated mean values and latent class proportions for all six latent profiles of right-wing attitudes (i.e., affinity to right-wing authoritarian regimes, trivialization of National Socialism, chauvinism, xenophobia, social Darwinism, and antisemitism) among a sample of German ninth-graders. For each scale, a higher value indicates stronger affirmative attitudes 
statements, they are referred to as "the indifferent". Class five $(N=215)$ had medium mean values for social Darwinism and antisemitism and medium to high mean values regarding chauvinism, xenophobia, and the trivialization of National Socialism, but the second highest mean value for the affinity to right-wing authoritarian regimes. The label assigned to class five is thus the "the authoritarians." The sixth class $(N=92)$ was the smallest class but had significantly higher mean values regarding all right-wing extremism items. Especially the mean values for the affinity to right-wing authoritarian regimes and chauvinism were high and close to the maximum. Participants in this class approved almost all statements and are thus referred to as "the extremists."

According to the results from Tukey's post hoc test, most mean values differed significantly between the classes. Exceptions were only found among "the indifferent" class, who showed no significant differences in means compared to "the anti-authoritarians" regarding chauvinism and xenophobia. Furthermore, this class showed no significant differences in mean values compared to "the authoritarians" regarding social Darwinism and antisemitism.

Except for "the authoritarians" and "the extremists," the mean values for chauvinism and xenophobia were the highest of all mean scales within the classes. The affinity to rightwing authoritarian regimes is used as a factor for labeling two classes since most of the classes did not strongly differ in terms of patterns of approval level among the mean scales.

Overall, the results demonstrated a largely stacked class structure, in which the classes are similar in their progression patterns and mainly differ in their item values. The majority of the sample did not agree to the items measured in our survey and therefore showed no or no clear (measured) right-wing attitudes. Approximately, $4.8 \%$ of adolescents ("the authoritarians" and "the extremists," $N=307$ ) showed a strong to very strong approval of right-wing extremist attitudes.

\section{Logistic Regression Models}

To analyze the determinants of group membership, we ran multinomial logistical regressions with class affiliation as the dependent variable and perceived deprivation (relative, social, political), number of critical life events, victimization, property offences and violent offences, parental control, family conflict, and family cohesion as independent variables (see Table 3). Since "the opposing" class had the lowest mean values on all indicator variables, we chose it as the reference group. We report adjusted odds ratios (aOR), including 95\% confidence intervals, as effect sizes.

Regarding gender, only the coefficient for "the extremists" was significant ( $a O R=0.37$ ). This indicates a strong gender effect within this class, with boys having a much higher chance of being in this class than girls. For critical life events, no significant effects were found. Regarding relative deprivation, significant coefficients were found for "the antiauthoritarians" $(a O R=1.79)$ and "the authoritarians" $(a O R=2.07)$, as well as particularly strong coefficients for "the extremists" $(a O R=4.28)$. These results indicate a positive relationship between relative deprivation and right-wing attitudes, with a particularly strong association evident among "the extremists." On the other hand, regarding the feeling of receiving "more than the fair share" (i.e., feeling relatively favored), significant coefficients were found for "the generally opposing" $(a O R=0.81)$, "the anti-authoritarians" $(a O R=0.76)$, and "the indifferent" class $(a O R=0.71)$. These findings indicate a negative relationship between the feeling of being favored and having strong right-wing attitudes and are particularly strong among the largest group of "the opposing". Regarding 
Table 3 Multinomial logistic regression models with class affiliation as dependent variables and adjusted odds ratio (aOR) as coefficients

\begin{tabular}{|c|c|c|c|c|c|}
\hline \multicolumn{3}{|c|}{ versus Class 1 "The opposing" } & \multirow[b]{2}{*}{ Class 4} & \multirow[b]{2}{*}{ Class 5} & \multirow[b]{2}{*}{ Class 6} \\
\hline & Class 2 & Class 3 & & & \\
\hline & $\begin{array}{l}\text { "The gener- } \\
\text { ally oppos- } \\
\text { ing" }\end{array}$ & $\begin{array}{l}\text { "The anti- } \\
\text { authoritar- } \\
\text { ians" }\end{array}$ & "The indifferent" & $\begin{array}{l}\text { "The authoritar- } \\
\text { ians" }\end{array}$ & "The extremists" \\
\hline \multicolumn{6}{|l|}{ Gender (ref. Male) } \\
\hline Female & $\begin{array}{l}1.05 \\
{[0.88 ; 1.27]}\end{array}$ & $\begin{array}{l}0.80 \\
{[0.64 ; 1.01]}\end{array}$ & $\begin{array}{l}0.94 \\
{[0.75 ; 1.17]}\end{array}$ & $\begin{array}{l}0.84 \\
{[0.58 ; 1.21]}\end{array}$ & $\begin{array}{l}0.37 * * \\
{[0.18 ; 0.77]}\end{array}$ \\
\hline $\begin{array}{l}\text { Critical life } \\
\text { events }\end{array}$ & $\begin{array}{l}1.06 \\
{[0.97 ; 1.15]}\end{array}$ & $\begin{array}{l}0.99 \\
{[0.89 ; 1.10]}\end{array}$ & $\begin{array}{l}0.97 \\
{[0.87 ; 1.08]}\end{array}$ & $\begin{array}{l}1.04 \\
{[0.90 ; 1.21]}\end{array}$ & $\begin{array}{l}0.84 \\
{[0.56 ; 1.25]}\end{array}$ \\
\hline \multicolumn{6}{|c|}{ Relative deprivation (ref. "a fair share") } \\
\hline $\begin{array}{l}\text { "More than the } \\
\text { fair share" }\end{array}$ & $\begin{array}{l}0.81 * \\
{[0.67 ; 0.99]}\end{array}$ & $\begin{array}{l}0.76 * \\
{[0.59 ; 0.98]}\end{array}$ & $\begin{array}{l}0.71 * * \\
{[0.56 ; 0.91]}\end{array}$ & $\begin{array}{l}0.87 \\
{[0.59 ; 1.27]}\end{array}$ & $\begin{array}{l}1.18 \\
{[0.58 ; 2.39]}\end{array}$ \\
\hline $\begin{array}{l}\text { "Less than the } \\
\text { fair share" }\end{array}$ & $\begin{array}{l}1.23 \\
{[0.78 ; 1.93]}\end{array}$ & $\begin{array}{l}1.79 * \\
{[1.09 ; 2.94]}\end{array}$ & $\begin{array}{l}1.47 \\
{[0.91 ; 2.36]}\end{array}$ & $\begin{array}{l}2.07 * \\
{[1.10 ; 3.88]}\end{array}$ & $\begin{array}{l}4.28 * * \\
{[1.54 ; 11.86]}\end{array}$ \\
\hline Social deprivation & $\begin{array}{l}1.06 \\
{[0.94 ; 1.20]}\end{array}$ & $\begin{array}{l}0.95 \\
{[0.81 ; 1.11]}\end{array}$ & $\begin{array}{l}0.99 \\
{[0.85 ; 1.15]}\end{array}$ & $\begin{array}{l}0.92 \\
{[0.73 ; 1.15]}\end{array}$ & $\begin{array}{l}1.58^{*} \\
{[1.11 ; 2.25]}\end{array}$ \\
\hline $\begin{array}{l}\text { Political depriva- } \\
\text { tion }\end{array}$ & $\begin{array}{l}1.63^{* * * *} \\
{[1.46 ; 1.82]}\end{array}$ & $\begin{array}{l}1.93 * * * \\
{[1.67 ; 2.23]}\end{array}$ & $\begin{array}{l}2.26 * * * \\
{[1.98 ; 2.57]}\end{array}$ & $\begin{array}{l}2.26 * * * \\
{[1.81 ; 3.88]}\end{array}$ & $\begin{array}{l}2.57 * * * \\
{[1.67 ; 3.96]}\end{array}$ \\
\hline Discrimination & $\begin{array}{l}0.88 * \\
{[0.80 ; 0.97]}\end{array}$ & $\begin{array}{l}1.01 \\
{[0.91 ; 1.11]}\end{array}$ & $\begin{array}{l}0.98 \\
{[0.88 ; 1.08]}\end{array}$ & $\begin{array}{l}1.07 \\
{[0.93 ; 1.15]}\end{array}$ & $\begin{array}{l}0.88 \\
{[0.67 ; 1.15]}\end{array}$ \\
\hline Property offences & $\begin{array}{l}0.97 \\
{[0.91 ; 1.04]}\end{array}$ & $\begin{array}{l}1.01 \\
{[0.93 ; 1.09]}\end{array}$ & $\begin{array}{l}0.87 \\
{[0.79 ; 0.96]}\end{array}$ & $\begin{array}{l}0.96 \\
{[0.86 ; 1.08]}\end{array}$ & $\begin{array}{l}1.21 \\
{[0.97 ; 1.51]}\end{array}$ \\
\hline Violent offences & $\begin{array}{l}1.28 * \\
{[1.04 ; 1.58]}\end{array}$ & $\begin{array}{l}1.38 * * \\
{[1.09 ; 1.75]}\end{array}$ & $\begin{array}{l}1.94 * * * \\
{[1.59 ; 2.37]}\end{array}$ & $\begin{array}{l}1.93 * * * \\
{[1.51 ; 2.46]}\end{array}$ & $\begin{array}{l}1.90 * * \\
{[1.31 ; 2.75]}\end{array}$ \\
\hline Family cohesion & $\begin{array}{l}1.44 * * * \\
{[1.20 ; 1.71]}\end{array}$ & $\begin{array}{l}1.23 \\
{[1.00 ; 1.53]}\end{array}$ & $\begin{array}{l}1.57 * * * \\
{[1.26 ; 1.95]}\end{array}$ & $\begin{array}{l}1.15 \\
{[0.81 ; 1.65]}\end{array}$ & $\begin{array}{l}1.90 \\
{[0.96 ; 3.74]}\end{array}$ \\
\hline Parental control & $\begin{array}{l}0.87 \\
{[0.75 ; 1.01]}\end{array}$ & $\begin{array}{l}0.89 \\
{[0.73 ; 1.07]}\end{array}$ & $\begin{array}{l}0.64 * * * \\
{[0.54 ; 0.77]}\end{array}$ & $\begin{array}{l}0.74 * \\
{[0.56 ; 0.98]}\end{array}$ & $\begin{array}{l}0.99 \\
{[0.58 ; 1.69]}\end{array}$ \\
\hline Family conflict & $\begin{array}{l}1.21 * \\
{[1.03 ; 1.41]}\end{array}$ & $\begin{array}{l}1.10 \\
{[0.90 ; 1.35]}\end{array}$ & $\begin{array}{l}1.35^{* *} \\
{[1.10 ; 1.64]}\end{array}$ & $\begin{array}{l}1.17 \\
{[0.86 ; 1.59]}\end{array}$ & $\begin{array}{l}1.21 \\
{[0.64 ; 2.30]}\end{array}$ \\
\hline Victimization & $\begin{array}{l}1.19 \\
{[0.96 ; 1.48]}\end{array}$ & $\begin{array}{l}1.36 * \\
{[1.05 ; 1.76]}\end{array}$ & $\begin{array}{l}1.25 \\
{[0.96 ; 1.62]}\end{array}$ & $\begin{array}{l}1.01 \\
{[0.67 ; 1.50]}\end{array}$ & $\begin{array}{l}0.84 \\
{[0.38 ; 1.84]}\end{array}$ \\
\hline
\end{tabular}

$* p<.05, * * p<.01, * * * p<0.001$

social deprivation, only the coefficient for "the extremists" was significant ( $a O R=1.58)$, which indicates that a high value for social deprivation increases the likelihood of belonging to the class of "the extremists." The coefficients for political deprivation were significant within all classes. Here, the stepwise increasing value indicates a strong positive and almost linear relationship between political deprivation and right-wing attitudes. Feeling politically deprived can thus be seen as a strong risk factor for right-wing attitudes. Regarding discrimination, the only significant effect was found for "the generally opposing" $(a O R=0.88)$, which indicates a positive effect of the experience of discrimination within "the opposing" in comparison to "the generally opposing." Since this effect cannot be explained by our theoretical approach and we found no significant effects for other classes, these results can be seen as ambiguous and not clearly interpretable. Regarding delinquency, we found no significant effects for property offenses but found significant 
effects for violent offences among all classes. These findings indicate that adolescents who had previously committed violent offences had a greater chance of belonging to one of the three classes with higher right-wing attitudes. The coefficients for parental control were only significant for "the indifferent" $(a O R=0.64)$ and "the authoritarians" $(a O R=0.74)$, indicating a protective effect of strong parental control. No statistically significant effects were found for the other classes. Higher values for family cohesion and family conflict increased the chances of belonging to "the generally opposing" or "the indifferent" class. Participants who experienced victimization had a higher chance of being in the class of "the anti-authoritarians."

\section{Discussion and Conclusion}

Some limitations of the data must be mentioned first. All data are based on adolescent selfreports, which means that responses may be biased due to social desirability. Since many items concern attitudes that can be considered deviant, this issue may be particularly relevant to the study. Social desirability and other potential control variables were not included in the regression model due to survey time constraints, which somewhat limits the findings. However, this limitation was minimized by providing participants with information about data protection regulations, anonymity, and confidentiality, as well as creating maximum space between participants in the classrooms. The mean scales used in our analyses (e.g., for right-wing attitudes) were based on 5-point Likert scales. For many statistical purposes, a higher scale level is required or would at least be preferable. The numbers of items for the mean scales are also minimal due to space constrains in the survey and should therefore be higher in further research. The high number of missing values indicates a possible premature end to the survey due to a lack of time, decreasing motivation, or the inability to participate for the duration of the survey. This may have increased the error variance due to carelessness in responding. The completion rate of each survey page was checked, and no conspicuous rates were found for any of the pages, which thereby indicates no systematic premature completion as a result of single items. Furthermore, our findings are unable to indicate causal relationships since the analyses were based on cross-sectional data and thus cannot specify the direction of effects in a causal sense. The findings are not representative for the whole of Germany and cannot be generalized to adult populations. However, since the aim of the present study was to identify vulnerable groups and not to present representative valid prevalence, and since the focus was deliberately placed on adolescents, this limitation is tolerable.

Considering that previous research on right-wing attitudes merely reflects differences on a variable level, mostly represented by mean values, our approach sought to examine different constellations of attitudinal patterns within a population. Latent profile analysis is a person-centered approach used for the analysis of the specific characteristics of different groups. This provides the opportunity to highlight different groups or profiles relating to attitudes and behaviors, particularly among vulnerable individuals. The method is highly flexible and can compare models with multiple latent classes to identify the solution that best fits the data. Our analysis provides valuable results regarding the questions of which attitudes co-occur and which distinct vulnerabilities relate to which attitudinal patterns. In addition, it is possible to point to qualitative differences in attitudes that are relevant to 
radicalization (e.g., typologies of biographical radicalization processes). In this way, qualitative and quantitative research approaches can be more closely interlinked.

Our analysis of the specific class characteristics showed that the sizes of the classes differed. More than half of the adolescents in the sample belonged to a class characterized by a strong disagreement with all dimensions of right-wing attitudes. Three classes with predominantly little approval of or indifferent opinions about right-wing attitudes each comprised between 13 and $16 \%$ of the sample. When combined, the two classes characterized by high approval of right-wing attitudes included approximately $5 \%$ of the sample. This is, however, not a limitation of our analysis because the classes were large enough to produce significant results. In addition, variance resulting from the different extents of agreement/disagreement with the statements is required for the analyses.

The analysis demonstrated that vulnerability varies across the classes, except for experiences of political deprivation and the perpetration of violent offences. This finding aligns with previous research that has shown strong associations between deprivation, delinquency, and radicalization (Kliem et al., 2018). The class labeled as "the extremists" showed distinct characteristics, such as male gender and exceedingly high feelings of relative deprivation and social deprivation, which are thus regarded as unique features of this group. This corroborates previous research that has identified male gender (Arnis, 2016) and deprivation (Stöss, 2010) as risk factors for radicalization into right-wing extremism. Our findings could propose a starting point for selective prevention given that "the extremists" were the only class that showed a significant association with gender. Strong feelings of political deprivation and a tendency toward the perpetration of violent offences were also identified as distinct characteristics of this class. Family bonds (Hirschi, 1969) and experiences of victimization (Agnew, 2017), on the other hand, did not play a role in belonging to "the extremists." "The authoritarians" demonstrated a different pattern of vulnerability. In contrast to the previous class, gender and social deprivation did not affect the likelihood of belonging to "the authoritarians," with the largest class of "the opposing" as a reference. Nevertheless, this class was characterized by relative and political deprivation, as well as the perpetration of violent offences and lower parental control. Besides political deprivation and a tendency to engage in violent offences, family bonds predominantly characterized "the indifferent" class. In comparison to "the opposing", high cohesion and more family conflict, as well as lower parental control, determined the membership of this class. "The anti-authoritarians" were characterized by a relatively small, but significant, influence of relative and political deprivation, violent offences, and victimization. Higher levels of relative and political deprivation, the perpetration of violent offences, family cohesion, and family conflict, as well as less experiences of discrimination, all increased the likelihood of belonging to "the generally opposing."

The present findings can form an important step toward the specification of prevention measures. Prevention approaches that target all groups (i.e., universal or "one-size-fits-all") are generally not effective. Our findings highlight the different needs of individual groups. It therefore seems necessary to differentiate concepts more strongly and to pursue distinct prevention goals for specific target groups (i.e. selective and indicated prevention). This is an important implication for policymakers regarding the allocation of funds, and it can be done, for example, by specifically addressing groups such as male "loners," or other young people, who experience social and relative disadvantages and are at risk for radicalization. In addition, gender-specific work is required. Preventive efforts can further address adolescents that are already entangled in radical environments or promote radical attitudes, which might correspond to the latent class of "the extremists" (i.e., indicated prevention). 
Large-scale media or school-based campaigns may not be as successful given that they fail to address unique risk factors for radicalization trajectories.

In general, the distinction of primary, secondary, and tertiary prevention stems from the medical field of public health, for instance, regarding early interventions in mental health (Caplan, 1964; Caplan \& Caplan, 2000; Simeonsson, 1991), but it was also popularized in criminological research, such as crime prevention (Brantingham \& Faust, 1976; Brantingham et al., 2005). Primary prevention aims to prevent problems of any kind before they occur. It is done by preventing exposure to hazards that cause these problems, for instance, by changing environmental design, by providing education to change patterns of thinking or behavior that can lead to these problems, and by increasing resilience. Secondary prevention aims to reduce the impact of a problem that has already occurred. This is done by identifying and treating it as early as possible to stop or slow its progression, promoting personal strategies to prevent exacerbations, and implementing programs to restore it to its original status (e.g., in high risk neighborhoods). Tertiary prevention aims to mitigate the effects of a problem that have already occurred or is ongoing. This can be the return to a prior state (e.g., by disengaging with a group) or the discarding of problematic attitudes (deradicalization). Research on Countering Violent Extremism (CVE) offers insight to improve tertiary prevention efforts (Altier et al., 2017; Bubolz \& Simi, 2015; Cherney et al., 2021; Dalgaard-Nielsen, 2018; Horgan et al., 2017a; Windisch et al., 2016). All three areas of prevention can potentially benefit from our findings, as we identified unique characteristics such as male gender, as well as high levels of relative disadvantage and social deprivation within the group of "the extremists" that can inform the development of primary prevention programs (e.g., include educational resources on social deprivation), secondary prevention (e.g., focus on males), and tertiary prevention (e.g., address the identified risk factors when planning measures of deradicalization). "The extremists" were also characterized by strong feelings of political deprivation and a tendency to commit violent offences. Prevention measures targeted at "the extremists" should thus place greater emphasis on the aspects of relative and social deprivation, which is also supported by studies showing that relationships and especially immediate relatives such as parents play a major role in the disengagement process from extremist groups (Windisch et al., 2016). In addition, the issue of violence should be considered. The deradicalization of this group should first and foremost be addressed through tertiary prevention measures. Given that family ties were found to play a role within the group of "the indifferent", the involvement of family members in prevention measures targeted at this group could potentially form a fruitful approach. In the case of the "anti-authoritarians", it is also evident that the topic of victimization should be included. While groups two to four (i.e., "the generally opposing", "the anti-authoritarians", "the indifferent", and "the authoritarians") can be addressed with secondary prevention measures, since they already show at least some problematic attitudes, the potential radicalization of group one (i.e., "the opposing") can be preliminarily addressed with primary prevention measures.

Regarding the development of prevention measures for specific groups, it also seems necessary to investigate in which places prevention work can take place for each group. Examples of prevention settings include out-of-school places, such as the Internet, which represents an important domain for young people. For this reason, target group-specific media resources must be developed. An important building block in prevention work is, above all, that young people perceive the resources to be appealing and that they have both democratic and recreational value.

The present results can potentially improve the effectiveness of prevention measures and can therefore be employed as a useful tool to prevent young people from developing 
right-wing attitudes. The findings are limited to the field of right-wing extremism and cannot be transferred to phenomena such as Islamism or left-wing extremism. Our analysis approach should thus be employed in further research to analyze latent profiles of left-wing and Islamist attitudes among adolescents.

Acknowledgements The authors thank the German Federal Ministry of Education and Research (BMBF) for funding the project "Radicalisation within the digital age - risks, processes and strategies for prevention".

Author Contribution C.P.S. conceived and presented the idea. He developed the theoretical framework, wrote most parts of the manuscript, and supported the statistical analysis, which was conducted by S.T., who also provided the "Latent Profile Analysis and Logistic Regression" section, methodological knowledge for the analysis, and supervision for the research process. J.B. contributed the "Results" section as well as tables and supported the statistical analysis. L.L. contributed interpretations and implication of the results as well as parts of the theoretical background. L.-R.G. and C.P.S. were responsible for survey design and data collection. Furthermore, L.-R.G. provided parts of the section on vulnerability. T.B. contributed guidance in the research process and for the interpretation of the results. All authors discussed the results and contributed to the final manuscript.

Funding This research was realized within the RadigZ-project funded by the German Federal Ministry of Education and Research (BMBF). The sponsor was not involved in study design or in collection, analysis and interpretation of data, in writing of the report, or in the decision to submit the article for publication.

Data Availability The data are not publicly available due to privacy restrictions. Anonymized data that support the findings of this study are only available upon reasonable request from the Criminological Research Institute of Lower Saxony.

Code Availability Not applicable.

\section{Declarations}

Ethics Approval All procedures performed in studies involving human participants were in accordance with the ethical standards of the ethics committee of the Georg-August-Universität Göttingen and with the 1964 Helsinki declaration and its later amendments or comparable ethical standards.

Consent to Participate Informed consent was obtained from all individual participants included in the study, including parents or legal guardians.

Conflict of Interest The authors have no competing interests to declare that are relevant to the content of this article.

Open Access This article is licensed under a Creative Commons Attribution 4.0 International License, which permits use, sharing, adaptation, distribution and reproduction in any medium or format, as long as you give appropriate credit to the original author(s) and the source, provide a link to the Creative Commons licence, and indicate if changes were made. The images or other third party material in this article are included in the article's Creative Commons licence, unless indicated otherwise in a credit line to the material. If material is not included in the article's Creative Commons licence and your intended use is not permitted by statutory regulation or exceeds the permitted use, you will need to obtain permission directly from the copyright holder. To view a copy of this licence, visit http://creativecommons.org/licenses/by/4.0/.

\section{References}

Agnew, R. (2010). A general strain theory of terrorism. Theoretical Criminology, 14(2), 31-153. https:// doi.org/10.1177/1362480609350163 
Agnew, R. (2017). General strain theory and terrorism. In G. Lafree \& J. D. Freilich (Eds.), The handbook of the criminology of terrorism (pp. 121-132). John Wiley \& Sons.

Ahmed, R., Albrecht, S., Fielitz, M., Junk, J., Kahl, M., Marcks, H., Mullis, D., Quent, M., and Sold, M., (2020). Eine neue Welle des Rechtsterrorismus/ Transnationale Sicherheitsrisiken. In: BICC Bonn International Center for Conversion, HSFK Leibniz-Institut Hessische Stiftung Friedensund Konfliktforschung, and IFSH Institut für Friedensforschung und Sicherheitspolitik an der Universität Hamburg (Eds), Friedensgutachten 2020: Im Schatten der Pandemie: letzte Chance für Europa [Peace Report 2020: In the Shadow of the Pandemic: Last Chance for Europe] (pp. 141-149). Transcript.

Akins, J. K., \& Winfree, L. T. (2017). Social learning theory and becoming a terrorist: New challenges for a general theory. In G. Lafree \& J. D. Freilich (Eds.), The handbook of the criminology of terrorism (pp. 133-149). John Wiley \& Sons.

Albert, M., Hurrelmann, K., Quenzel, G., \& TNS Infratest (2015). Jugend 2015: Eine pragmatische Generation im Aufbruch: 17. Shell Jugendstudie - Eine pragmatische Generation im Aufbruch [Youth 2015: A pragmatic generation on the move: 17th Shell Youth Study]. Fischer Taschenbuch Verlag.

Altier, M. B., Boyle, L. E., Shortland, N. D., \& Horgan, J. G. (2017). Why they leave: An analysis of terrorist disengagement events from eighty-seven autobiographical accounts. Security Studies, 26(2), 305-332. https://doi.org/10.1080/09636412.2017.1280307

Alwin, D. F., \& Krosnick, J. A. (1991). Aging, cohorts, and the stability of sociopolitical orientations over the life span. American Journal of Sociology, 97(1), 169-195. https://doi.org/10.1086/229744

Arnis, M. (2016). Devianz und Delinquenz von Kindern und Jugendlichen weiblichen Geschlechts [Deviance and delinquency of children and adolescents of female gender]. In J. Reinecke, M. Stemmler, \& J. Wittenberg (Eds.), Devianz und Delinquenz im Kindes- und Jugendalter (pp. 53-73). Springer Fachmedien Wiesbaden.

Aslan, E., Erşan Akkılıç, E., \& Hämmerle, M. (2018). Islamistische Radikalisierung: Biografische Verläufe im Kontext der religiösen Sozialisation und des radikalen Milieu [Islamist Radicalization: Biographical Trajectories in the Context of Religious Socialization and the Radical Milieu]. Springer VS.

Asparouhov, T., \& Muthén, B. O. (2014). Auxiliary variables in mixture modeling: Three-step approaches using Mplus. Structural Equation Modeling: A Multidisciplinary Journal, 21(3), 329-341. https://doi. org/10.1515/mkr-2016-0302

Baier, D., Manzoni, P., \& Bergmann, M. C. (2016). Einflussfaktoren des politischen Extremismus im Jugendalter - Rechtsextremismus, Linksextremismus und islamischer Extremismus im Vergleich [Factors influencing political extremism in adolescence - right-wing extremism, left-wing extremism and islamic extremism in comparison]. Journal of Criminology and Penal Reform, 99(3), 171198. https://doi.org/10.1515/mkr-2016-0302

Baier, D., Manzoni, P., Haymoz, S., Isenhardt, A., Kamenowski, M., \& Jacot, C. (2019). Politischer Extremismus unter Jugendlichen in der Schweiz [Political Extremism among Young People in Switzerland]. Zeitschrift Für Jugendkriminalrecht Und Jugendhilfe, 30(1), 4-11.

Beelmann, A. (2020). A social-developmental model of radicalization: A systematic integration of existing theories and empirical research. International Journal of Conflict and Violence, 14, 1-14. https://doi. org/10.4119/ijcv-3778

Benslama, F. (2017). Der Übermuslim: Was junge Menschen zur Radikalisierung treibt [What Drives Young People to Radicalization]. Matthes \& Seitz.

Bergmann, M. C., Baier, D., Rehbein, F., \& Mößle, T. (2017). Jugendliche in Niedersachsen: Ergebnisse des Niedersachsensurveys 2013 und 2015 [Young people in Lower Saxony: Results of the Lower Saxony survey 2013 and 2015] (KFN-Research Reports, Vol. 131). Kriminologisches Forschungsinstitut Niedersachsen.

Bergmann, M. C., Kliem, S., Krieg, Y., \& Beckmann, L. (2019). Jugendliche in Niedersachsen: Ergebnisse des Niedersachsensurveys 2017 [Young people in Lower Saxony: Results of the Lower Saxony survey 2017] (KFN-Research Reports, Vol. 141). Kriminologisches Forschungsinstitut Niedersachsen.

Bhui, K., Warfa, N. \& Jones, E. (2014). Is violent radicalisation associated with poverty, migration, poor self-reported health and common mental disorders? PloS One, 9(3). https://doi.org/10.1371/journal. pone.0090718

Bloom, M., \& Horgan, J. (2019). Small arms: Children and terrorism (Cornell scholarship online). Cornell University Press.

Böckler, N. \& Zick, A. (2015). Wie gestalten sich Radikalisierungsprozesse im Vorfeld jihadistisch-terroristischer Gewalt? Perspektiven aus der Forschung [How do radicalization processes take shape in the run-up to jihadist-terrorist violence?] In D. Molthagen (Ed.), Handlungsempfehlungen zur Auseinandersetzung mit islamistischem Extremismus und Islamfeindlichkeit: Arbeitsergebnisse eines 
Expertengremiums der Friedrich-Ebert-Stiftung (pp. 99-121). Friedrich-Ebert-Stiftung, Forum Berlin.

Borum, R. (2012). Radicalization into violent extremism I: A review of social science theories. Journal of Strategic Security, 4(4), 7-36. https://doi.org/10.5038/1944-0472.4.4.1

Bubolz, B. F., \& Simi, P. (2015). Leaving the world of hate: Life-course transitions and self-change. American Behavioral Scientist, 59(12), 1588-1608. https://doi.org/10.1177/0002764215588814

Brantingham, P., Brantingham, P., \& Taylor, W. (2005). Situational crime prevention as a key component in embedded crime prevention. Canadian Journal of Criminology and Criminal Justice, 47(2), 271292. https://doi.org/10.3138/cjccj.47.2.271

Brantingham, P. J., \& Faust, F. L. (1976). A conceptual model of crime prevention. Crime \& Delinquency, 22(3), 284-296. https://doi.org/10.1177/001112877602200302

Campelo, N., Oppetit, A., Neau, F., Cohen, D., \& Bronsard, G. (2018). Who are the European youths willing to engage in radicalisation? A multidisciplinary review of their psychological and social profiles. European Psychiatry, 52, 1-14. https://doi.org/10.1016/j.eurpsy.2018.03.001

Caplan, G. (1964). Principles of preventive psychiatry. Basic Books.

Caplan, G., \& Caplan, R. (2000). Principles of community psychiatry. Community Mental Health Journal, 36, 7-24. https://doi.org/10.1023/A:1001894709715

Coid, J. W., Ullrich, S., Bebbington, P., Fazel, S., \& Keers, R. (2016). Paranoid ideation and violence: Metaanalysis of individual subject data of 7 population Surveys. Schizophrenia Bulletin, 42(4), 907-915. https://doi.org/10.1093/schbul/sbw006

Corner, E., Gill, P., \& Mason, O. (2016). Mental health disorders and the terrorist: A research note probing selection effects and disorder prevalence. Studies in Conflict \& Terrorism, 39(6), 560-568. https://doi. org/10.1080/1057610X.2015.1120099

Cherney, A. (2020). Exploring youth radicalisation through the framework of developmental crime prevention: A case study of Ahmad Numan Haider. Current Issues in Criminal Justice., 32(3), 277291. https://doi.org/10.1080/10345329.2020.1784503

Cherney, A., Belton, E., Norham, S. A. B., \& Milts, J. (2020). Understanding youth radicalisation: An analysis of Australian data. Behavioral Sciences of Terrorism and Political Aggression. https://doi.org/10. 1080/19434472.2020.1819372

Cherney, A., Putra, I. E., Putera, V. S., Erikha, F., \& Magrie, M. F. (2021). The push and pull of radicalization and extremist disengagement: The application of criminological theory to Indonesian and Australian cases of radicalization. Journal of Criminology, 54(4), 407-424. https://doi.org/10.1177/26338 076211034893

Collins, L. M., \& Lanza, S. T. (2010). Latent class and latent transition analysis - with applications in the social, behavioral, and health sciences (Wiley Series in Probability and Statistics, v.718). Wiley \& Sons.

Dalgaard-Nielsen, A. (2018). Patterns of disengagement from violent extremism: A stocktaking of current knowledge and implications for couterterrorism. In K. Steiner \& A. Önnerfirs (Eds.), Expressions of Radicalization (pp. 273-293). Palgrave Macmillan.

Decker, O., \& Brähler, E. (Eds.). (2006). Vom Rand zur Mitte: Rechtsextreme Einstellung und ihre Einflussfaktoren in Deutschland [From the edge to the center. Right-wing extremist attitudes and their influencing factors in Germany]. Friedrich-Ebert-Stiftung.

Decker, O., Kiess, J., \& Brähler, E. (Eds.). (2013). Die Mitte im Umbruch: Rechtsextreme Einstellungen in Deutschland 2012 [The middle in transition: right-wing attitudes in Germany 2012] (2nd ed.). Dietz.

Decker, O., Kiess, J., \& Brähler, E. (Eds.). (2016). Die enthemmte Mitte: Autoritäre und rechtsextreme Einstellung in Deutschland [The disinhibited middle: Authoritarian and far-right attitudes in Germany]. Die Leipziger Mitte-Studie 2016. Psychosozial-Verlag.

Decker, O., Kiess, J., Schuler, J., Handke, B., \& Brähler, E. (2018). Die Leipziger Autoritarismus-Studie 2018: Methode, Ergebnisse und Langzeitverlauf [The Leipzig authoritarianism study 2018: Method, results, and long-term trajectory]. In O. Decker \& E. Brähler (Eds.), Flucht ins Autoritäre. Rechtsextreme Dynamiken in der Mitte der Gesellschaft: Die Leipziger Autoritarismus-Studie 2018 (pp. 65-116). Psychosozial-Verlag.

Decker, O., Kiess, J., Schuler, J., Handke, B., Pickel, G. \& Brähler, E. (2020). Die Leipziger Autoritarismus-Studie 2020: Methode, Ergebnisse und Langzeitverlauf [The Leipzig Authoritarianism Study 2020: Method, Results, and Long-Term Trajectory]. In O. Decker \& E. Brähler (Eds.), Autoritäre Dynamiken. Alte Ressentiments - neue Radikalität. Leipziger Autoritarismus Studie 2020 (pp. 27-88). Psychosozial-Verlag.

Dzhekova, R., Mancheva, M., Stoynova, N., \& Anagnostou, D. (2017). Monitoring radicalisation: A framework for risk indicators. Center for the Study of Democracy. 
Europol. (2021). European Union terrorism situation and trend report. Publications Office of the European Union.

Emmelkamp, J., Asscher, J. J., Wissink, I. B., \& Stams, G. J. J. M. (2020). Risk factors for (violent) radicalization in juveniles: A multilevel meta-analysis. Aggression and Violent Behavior. https://doi.org/10. 1016/j.avb.2020.101489

Farrington, D. P. (1986). Age and crime. In M. Tonry \& N. Morris (Eds.), Crime and justice: An annual review of research (7th ed., pp. 189-250). Chicago University Press.

Fok, C. C. T., Allen, J., \& Henry, D. (2014). The brief family relationship scale: A brief measure of the relationship dimension in family functioning. Assessment, 21(1), 67-72. https://doi.org/10.1177/10731 91111425856

German Federal Ministry of the Interior, Building and Community (2021a). Übersicht "Hasskriminalität": Entwicklung der Fallzahlen 2001-2020. [Overview Hatecrime]. https://www.bmi.bund.de/Share dDocs/downloads/DE/veroeffentlichungen/2021a/05/pmk-2020-uebersicht-hasskriminalitaet-entwi cklung-fallzahlen.pdf?_blob=publicationFile\&v=2. Accessed 11 Sept 2021.

German Federal Ministry of the Interior, Building and Community (2021b). Verfassungsschutzbericht 2020 [Annual Report of the Federal Office for the Protection of the Constitution 2020].

Gesis (2017). ALLBUS 2016: Fragebogendokumentation [ALLBUS 2016: Questionnaire documentation]. Material zu den Datensätzen der Studiennummern ZA5250 und ZA5251.

Goede, L.-R. (2019). Islamistische Einstellungen und Verhaltensweisen unter muslimischen Jugendlichen: Ergebnisse einer deutschlandweiten Jugendstudie [Islamist attitudes and behavior among Muslim Youth: Results of a Germany-wide youth study]. Zeitschrift Für Jugendkriminalrecht Und Jugendhilfe, 31, 204-213.

Goede, L.-R., Schröder, C.P. \& Lehmann, L. (2020). Perspektiven von Jugendlichen: Ergebnisse einer Befragung zu den Themen Politik, Religion und Gemeinschaft im Rahmen des Projektes "Radikalisierung im digitalen Zeitalter (RadigZ)" [Perspectives of adolescents: Results of a survey on politics, religion, and community as part of the "radicalization in the digital age (RadigZ)" project]. (KFN-Research Reports, Vol. 151). Kriminologisches Forschungsinstitut Niedersachsen.

Greve, W. (2007). Selbst und Identität im Lebenslauf [Self and identity in the life course]. In J. Brandstädter \& U. Lindenberger (Eds.), Entwicklungspsychologie der Lebensspanne (pp. 305-336). Kohlhammer.

Heine, F., \& Magazzini, T. (2020). Radicalisation and resilience case study Germany. European University Institute.

Heitmeyer, W. (2002). Gruppenbezogene Menschenfeindlichkeit: Die theoretische Konzeption und erste empirische Ergebnisse [Group-focused enmity: the theoretical conceptualization and initial empirical results]. In W. Heitmeyer (Ed.), Deutsche Zustände: Folge 1 (pp. 15-34). Suhrkamp.

Heitmeyer, W. (2008): Ideologie der Ungleichwertigkeit. Kern der Gruppenbezogenen Menschenfeindlichkeit [Ideology of Inequality. The core of group-focused enmity]. In W. Heitmeyer (Ed.), Deutsche Zustände: Folge 6 (pp. 31-39). Suhrkamp.

Herding, M. (2013). Forschungslandschaft und zentrale Befunde zu radikalem Islam im Jugendalter [Research landscape and key findings on radical islam in Adolescence]. In M. Herding (Ed.), Radikaler Islam im Jugendalter: Erscheinungsformen, Ursachen und Kontexte (pp. 21-39). Brandung.

Heyer, A., \& Gaßner, A. (2012). Anomia, Deprivation und Wertorientierung zur Vorhersage rechtsextremistischer Einstellungen - Eine empirische Studie mit Repräsentativdaten aus Deutschland [Anomia, deprivation, and value orientation in predicting right-wing extremist attitudes - An empirical study with representative data from Germany]. Österreichische Zeitschrift für Politikwissenschaft, 41(3), 277-298. https://doi.org/10.15203/ozp.18.vol41iss3

Hirschi, T. (1969). Causes of delinquency. University of California.

Horgan, J., Altier, M. B., Shortland, N., \& Taylor, M. (2017a). Walking away: The disengagement and de-radicalization of a violent right-wing extremist. Behavioral Sciences of Terrorism and Political Aggression, 9(2), 63-77. https://doi.org/10.1080/19434472.2016.1156722

Horgan, J. G., Taylor, M., Bloom, M., \& Winter, C. (2017b). From cubs to lions: A six stage model of child socialization into the Islamic state. Studies in Conflict \& Terrorism. https://doi.org/10.1080/10576 10X.2016.1221252

Hsu, H. Y., \& Newman, G. R. (2017). The situational approach to terrorism. In G. Lafree \& J. D. Freilich (Eds.), The handbook of the criminology of terrorism (pp. 150-161). John Wiley \& Sons.

Kessler, T., Mummendey, A., \& Klink, A. (1999). Soziale Identität und relative Deprivation: Determinanten individuellen und kollektiven Verhaltens in Ostdeutschland nach der Vereinigung [Social identity and relative deprivation: Determinants of individual and collective behavior in East Germany after unification]. In M. Schmitt \& L. Montada (Eds.), Gerechtigkeitserleben im wiedervereinigten Deutschland (pp. 213-262). Leske + Budrich. 
Kiess, J., \& Decker, O. (2016). Comparing right-wing extremist attitudes: Lack of research or lack of theory? In J. Kiess, O. Decker, \& E. Brähler (Eds.), German perspectives on right-wing extremism: Challenges for comparative analysis (pp. 11-29, Routledge studies in extremism and democracy, Vol. 35). Routledge Taylor \& Francis Group.

Klausen, J., Morrill, T., \& Libretti, R. (2016). The terrorist age-crime curve: An analysis of American Islamist terrorist offenders and age-specific propensity for participation in violent and nonviolent incidents. Social Science Quarterly, 97(1), 19-32. https://doi.org/10.1111/ssqu.12249

Koehler, D. (2020). Violent extremism, mental health and substance abuse among adolescents: Towards a trauma psychological perspective on violent radicalization and deradicalization. The Journal of Forensic Psychiatry \& Psychology, 31(3), 455-472. https://doi.org/10.1080/14789949.2020.1758752

Koehler, D. (2014). Right-wing extremist radicalization processes: The formers' perspective. JEX Journal EXIT-Deutschland. Zeitschrift für Deradikalisierung und demokratische Kultur, 1/2014, 307-377.

Kliem, S., Beckmann, L., Kudlacek, D., \& Krieg, Y. (2018). Vorurteile und vorurteilsgeleitete Straftaten. Ergebnisse der REX-Studie aus Schleswig-Holstein, 2018 [Prejudice and prejudice-led crime. Results of the REX Study from Schleswig-Holstein, 2018]. In A. Heller, O. Decker, \& E. Brähler (Eds.), Prekärer Zusammenhalt. Die Bedrohung des demokratischen Miteinanders in Deutschland (pp. 173-188). Psychosozial-Verlag.

Krieg, Y., Beckmann, L., \& Kliem, S. (2018). Regionalanalyse Rechtsextremismus in Schleswig-Holstein 2018 [Regional analysis of right-wing extremism in Schleswig-Holstein 2018] (KFN-Research Reports, Vol. 149). Kriminologisches Forschungsinstitut Niedersachsen.

Krieg, Y., \& Kliem, S. (2019). Rechtsextremismus unter Jugendlichen in Niedersachsen: Ergebnisse repräsentativer Wiederholungsbefragungen aus den Jahren 2013, 2015 und 2017 [Right-wing extremism among youth in Lower Saxony: Results of representative repeat surveys from 2013, 2015, and 2017]. Journal of Criminology and Penal Reform, 102(2), 135-153. https://doi.org/10.1515/ mks-2019-2017

Krieg, Y., Rook, L., Beckmann, L., \& Kliem, S. (2020). Jugendliche in Niedersachsen: Ergebnisse des Niedersachsensurveys 2019 [Young people in Lower Saxony: Results of the Lower Saxony survey 2019] (KFN-Research Reports, Vol. 154). Kriminologisches Forschungsinstitut Niedersachsen.

Kudlacek, D., Jukschat, N., \& Rook, L. (2018). Zur Entstehung von gewaltbereitem Extremismus: Ergebnisse einer Aufarbeitung einschlägiger Biografien [On the emergence of violent extremism: Results of a review of relevant biographies]. INDEs, 7(2), 48-60. https://doi.org/10.13109/inde.2018.7.2.48

Küpper, B., \& Zick, A. (2011). Geschlecht und Vorurteile: Eine empirische Analyse [Gender and prejudice: An empirical analysis]. In U. Birsl (Ed.), Rechtsextremismus und Gender (pp. 187-210). Verlag Barbara Budrich.

Küpper, B., Zick, A., \& Rump, M. (2021). Rechtsextreme Einstellungen in der Mitte 2020/21 [Right-wing attitudes in the middle 2020/21]. In A. Zick \& B. Küpper (Eds.), Die geforderte Mitte: Rechtsextreme und demokratiegefährdende Einstellungen in Deutschland 2020/21 (pp. 75-111). Dietz.

Lösel, F., King, S., Bender, D., \& Jugl, I. (2018). Protective factors against extremism and violent radicalization: A systematic review of research. International Journal of Developmental Science, 12(1-2), 89-102. https://doi.org/10.3233/DEV-170241

Lützinger, S. (Ed.). (2010). Die Sicht der Anderen: Eine qualitative Studie zu Biographien von Extremisten und Terroristen [The view of others: A qualitative study of extremist and terrorist biographies]. Luchterland Verlag.

Mansel, J., \& Spaiser, V. (2013). Ausgrenzungsdynamiken: In welchen Lebenslagen Jugendliche Fremdgruppen abwerten [Exclusion dynamics: In which life situations young people devalue foreign groups]. Beltz Juventa.

McCauley, C., \& Moskalenko, S. (2008). Mechanisms of political radicalization: Pathways toward terrorism. Terrorism and Political Violence, 20(3), 415-433. https://doi.org/10.1080/09546550802073367

Meeus, W. (2015). Why do young people become Jihadists? A theoretical account on radical identity development. European Journal of Developmental Psychology, 12(3), 275-281. https://doi.org/10.1080/ 17405629.2015.1024106

Moghaddam, F. M. (2005). The staircase to terrorism: A psychological exploration. The American Psychologist, 60(2), 161-169. https://doi.org/10.1037/0003-066X.60.2.161

Muthén, L. K., \& Muthén, B. O. (2017). Mplus user's guide: Eighth edition. https://www.statmodel.com/ download/usersguide/MplusUserGuideVer_8.pdf. Accessed 11 Sept 2021.

Muxel, A. (2020). Political radicalism among the younger generations. Youth and Globalization, 2(2), 123136. https://doi.org/10.1163/25895745-02020001

Neumann, P. R. (2013). The trouble with radicalization. International Affairs, 89(4), 873-893. https://doi. org/10.1111/1468-2346.12049 
Neumann, P. R. (2016). Der Terror ist unter uns: Dschihadismus und Radikalisierung in Europa [Terror is Among Us: Jihadism and Radicalization in Europe]. Bundeszentrale für politische Bildung.

Niemi, R. G., \& Hepburn, M. A. (2010). The rebirth of political socialization. Perspectives on Political Science, 24(1), 7-16. https://doi.org/10.1080/10457097.1995.9941860

Nylund, K. L., Asparouhov, T., \& Muthén, B. O. (2007). Deciding on the number of classes in latent class analysis and growth mixture modeling: A Monte Carlo simulation study. Structural Equation Modeling: A Multidisciplinary Journal, 14(4), 535-569. https://doi.org/10.1080/10705510701575396

Oosterhoff, B., Shook, N. J., Clay, R., \& Metzger, A. (2017). Differential and domain-specific associations among right-wing authoritarianism, social dominance orientation, and adolescent delinquency. Personality and Social Psychology Bulletin, 43(9), 1296-1310. https://doi.org/10.1177/0146167217 711937

Orav, A., Shreeves, R., \& Radjenovic, A. (2018). Radicalisation and counter-radicalisation: A gender perspective. European Parliamentary Research Service.

Pauwels, L. J. R., \& Heylen, B. (2020). Perceived group threat, perceived injustice, and self-reported rightwing violence: An integrative approach to the explanation right-wing violence. Journal of interpersonal violence, 35(21-22), 4276-43022. https://doi.org/10.1177/0886260517713711

Pauwels, L., \& de Waele, M. (2014). Youth involvement in politically motivated violence: Why do social integration, perceived legitimacy, and perceived discrimination matter? International Journal of Conflict and Violence, 8(1), 134-153. https://doi.org/10.4119/ijcv-3050

Pfundmair, M., Paulus, M., \& Wagner, E. (2020). Activism and radicalism in adolescence: An empirical test on age-related differences. Psychology, Crime \& Law. https://doi.org/10.1080/1068316X. 2020.1850725

Pisoiu, D. (2013). Theoretische Ansätze zur Erklärung individueller Radikalisierungsprozesse: eine kritische Beurteilung und Überblick der Kontroversen [Theoretical approaches to explaining individual radicalization processes: A critical assessment and overview of controversies]. Journal EXIT-Deutschland. Zeitschrift für Deradikalisierung und demokratische Kultur(1), 41-87.

Ravndal, J. A., Thorstensen, M., Jupskas, A. R., Macklin, G. (2021). RTV Trend Report 2021. Rightwing terrorism and violence in Western Europe, 1990 - 2020. Center for Research on Extremism: The Extreme Right, Hate Crime and Political Violence, University of Oslo.

Rekker, R., Keijsers, L., Branje, S., \& Meeus, W. (2015). Political attitudes in adolescence and emerging adulthood: Developmental changes in mean level, polarization, rank-order stability, and correlates. Journal of Adolescence, 41, 136-147. https://doi.org/10.1016/j.adolescence.2015.03.011

Rottweiler, B., Gill, P., \& Bouhana, N. (2021). Individual and environmental explanations for violent extremist intentions: A German nationally representative survey study. Justice Quarterly. https:// doi.org/10.1080/07418825.2020.1869807

Runciman, W. G. (1966). Relative deprivation and social justice. University of California Press.

Sageman, M. (2004). Understanding terror networks. University of Pennsylvania Press.

Sageman, M. (2008). Leaderless Jihad: Terror networks in the twenty-first century. University of Pennsylvania Press.

Schmitt, M., Maes, J., \& Gollwitzer, M. (2003). Längsschnittliche Effekte relativer Deprivation und relativer Privilegierung auf Fremdenfeindlichkeit im wiedervereinigten Deutschland [Longitudinal effects of relative deprivation and relative privilege on xenophobia in reunified Germany]. In E. H. Witte (Ed.), Sozialpsychologie politischer Prozesse: Beiträge des 18. Hamburger Symposions zur Methodologie der Sozialpsychologie (pp. 58-84). Pabst.

Sears, D. O. (1983). The persistence of early political predispositions: The roles of attitude object and life stage. In L. Wheeler \& P. Shaver (Eds.), Review of personality and social psychology (4th ed., pp. 79-116). SAGE Publications.

Sears, D. O. (1990). Whither political socialization research? The question of persistence. In O. Ichilov (Ed.), Political Socialization, Citizenship Education, and Democracy (pp. 69-97). Teachers College Press.

Seaton, E. K., Yip, T., Morgan-Lopez, A., \& Sellers, R. M. (2012). Racial discrimination and racial socialization as predictors of African American adolescents' racial identity development using latent transition analysis. Developmental Psychology, 48(2), 448-458. https://doi.org/10.1037/ a0025328

Seipel, C., \& Rippl, S. (2000). Ansätze der Rechtsextremismusforschung - ein empirischer Theorienvergleich [Approaches to right-wing extremism research - An empirical comparison of theories]. Zeitschrift für Soziologie der Erziehung und Sozialisation, 20(3), 303-318. https://doi.org/10. 25656/01:10971

Silber, M. D., \& Bhatt, A. (2007). Radicalization in the West: The homegrown threat. Police Department New York. 
Siller, L., Edwards, K. M., \& Banyard, V. (2020). Violence typologies among youth: A latent class analysis of middle and high school youth. Journal of Interpersonal Violence. https://doi.org/10.1177/ 0886260520922362

Simeonsson, R. J. (1991). Primary, secondary, and tertiary prevention in early intervention. Journal of Early Intervention, 15(2), 124-134. https://doi.org/10.1177/105381519101500202

Stöss, R. (2010). Rechtsextremismus im Wandel [Right-wing extremism in transition] (3rd ed.). Friedrich Ebert Stiftung.

Talaska, C. A., Fiske, S. T., \& Chaiken, S. (2008). Legitimating racial discrimination: Emotions, not beliefs, best predict discrimination in a meta-analysis. Social Justice Research, 21(3), 263-396. https://doi.org/10.1007/s11211-008-0071-2

Tomczyk, S., Isensee, B., \& Hanewinkel, R. (2016). Latent classes of polysubstance use among adolescents - A systematic review. Drug and Alcohol Dependence, 160, 12-29. https://doi.org/10.1016/j. drugalcdep.2015.11.035

Tomczyk, S., Schomerus, G., Stolzenburg, S., Muehlan, H., \& Schmidt, S. (2018). Who is seeking whom? A person-centred approach to help-seeking in adults with currently untreated mental health problems via latent class analysis. Social Psychiatry and Psychiatric Epidemiology, 53(8), 773-783. https://doi.org/10.1007/s00127-018-1537-7

Torney-Purta, J. (2004). Adolescents' political socialization in changing contexts: An international study in the spirit of Nevitt Sanford. Political Psychology, 25(3), 465-478. https://doi.org/10.1111/j.14679221.2004.00380.x

Veldhuis, T., \& Staun, J. (2009). Islamist radicalisation: A root cause model (Clingendael Security Paper, no. 12). Netherlands Institute of International Relations Clingendael.

Wang, J., Iannotti, R. J., Luk, J. W., \& Nansel, T. R. (2010). Co-occurrence of victimization from five subtypes of bullying: Physical, verbal, social exclusion, spreading rumors, and cyber. Journal of Pediatric Psychology, 37(4), 289-295. https://doi.org/10.1093/jpepsy/jsq048

Watts, M. W. (1999). Are there typical age curves in political behavior? The "age invariance" hypothesis and political socialization. Political Psychology, 20(3), 477-499. https://doi.org/10.1111/0162-895X. 00153

Weatherston, D., \& Moran, J. (2003). Terrorism and mental illness: Is there a relationship? International Journal of Offender Therapy and Comparative Criminology, 47(6), 698-713. https://doi.org/10.1177/ $0306624 \mathrm{X} 03257244$

Wikström, P.-O.H., \& Bouhana, N. (2017). Analyzing radicalization and terrorism: A situational action theory. In G. Lafree \& J. D. Freilich (Eds.), The handbook of the criminology of terrorism (pp. 175-186). John Wiley \& Sons.

Wiktorowicz, Q. (2005). Radical Islam rising: Muslim extremism in the west. Rowman \& Littlefield Publishers.

Windisch, S., Simi, S., Ligon, G. S., \& McNeel, H. (2016). Disengagement from ideologically-based and violent organizations: A systematic review of the literature. Journal of Deradicalization, 9, 1-38.

Wolfowicz, M., Litmanovitz, Y., Weisburd, D., \& Hasisi, B. (2020). A field-wide systematic review and meta-analysis of putative risk and protective factors for radicalization outcomes. Journal of Quantitative Criminology, 36, 407-447. https://doi.org/10.1007/s10940-019-09439-4

Wong, T. M. L., Slotboom, A.-M., \& Bijleveld, C. C. J. H. (2010). Risk factors for delinquency in adolescent and young adult females: A European review. European Journal of Criminology, 7(4), 266-284. https://doi.org/10.1177/1477370810363374

Yu, D., Smith, E. P., \& Oshri, A. (2019). Exploring racial-ethnic pride and perceived barriers in positive youth development: A latent profile analysis. Applied Developmental Science. https://doi.org/10. 1080/10888691.2019.1640607

Zick, A., Küpper, B., \& Berghan, W. (Eds.). (2019). Verlorene Mitte - feindselige Zustände: Rechtsextreme Einstellungen in Deutschland 2018/19 [The lost center - hostile conditions: Right-wing attitudes in Germany 2018/2019]. Dietz.

Zick, A., Küpper, B., \& Krause, D. (Eds.). (2016). Gespaltene Mitte - feindselige Zustände: Rechtsextreme Einstellungen in Deutschland 2016 [Divided center - hostile condition: Right-wing attitudes in Germany 2016]. Dietz.

Publisher's Note Springer Nature remains neutral with regard to jurisdictional claims in published maps and institutional affiliations. 